\title{
A Numerical Investigation of The Fracture Energy of Materials for Fuel Cell End Plates
}

\author{
Adem Avcu* (D), Naghdali Choupani $\mathbb{B}$, Gökhan Tüccar (1) \\ Mechanical Engineering Department/Faculty of Engineering /Adana Alparslan Türkeş Science and Technology University /Adana, Turkey
}

\begin{abstract}
Nowadays, with increasing energy requirements, the use of clean energy resources has become important. Fuel cells are an important key for clean energy technology due to wide range of utilization areas such as automotive, portable power applications, electricity generation, space, aviation and naval technologies. Additionally, they have many significant properties such as not producing harmful gases, therefore they do not cause environmental and chemical pollution. Besides, they have not any moving parts, also they do not produce noise. By comparison to fossil fuel, fuel cells have high efficiency that reaches up to $60 \%$ in appropriate conditions. Proton Exchange Membrane Fuel Cell (PEMFC) has many advantages than other fuel cell types due to simple structure, higher efficiency and low operating temperature. PEMFC may consist of one or more stacks to generate more electricity. End plate of PEMFC holds together all parts of it. Therefore, the material selection for end plate is important to provide safe conditions. To use PEMFC safely, investigation of material fracture energy is required to decide that the material is in safe conditions or not. There are three fracture energy modes which are mode I, mode II and mode III. There are many methods to investigate failure of material at different modes. Unlike other methods, Arcan specimen gives facility to evaluate of mode I, mode II and mixed modes. The main purpose of this paper was to compare the results of fracture energy (stain energy release rate) of different materials for end plates in fuel cells. Another goal was to select a suitable material was selected as PEMFC end plate.
\end{abstract}

Keywords: PEMFC, End plate, Fracture energy, Strain energy release rate.

\section{INTRODUCTION}

Fossil fuels are used for energy procurement widely, so environmental pollution rises due to harmful gases release. The usage of clean energy sources has started to increase in order to prevent environmental pollution. For this reason, fuel cells have seen as a significant option among clean energy sources with its positive sides. Besides, research and development on fuel cells have become important issue. There are advantages of fuel cell's properties such as, being environmentally and friendly, not producing harmful gases, high efficiency, noiseless, no moving parts and therefore low maintenance required. At First, fuel cells were used in space and marine technology, usage of them has started to become more widespread with the great advances in fuel cells $[1,2]$.

Fuel cells are devices that convert chemical energy to electrical energy directly. They generally produce electricity and water by the reaction of Hydrogen and Oxygen. As a result of chemical reaction, they do not create harmful waste for the environment. Only water and heat are produced after chemical reaction, it is the most important feature of fuel cells in energy production [2-5].

Generally, fuel cells are classified as Alkaline Fuel Cell (AFC), Direct Methanol Fuel Cell (DMFC), Proton Exchange Membrane Fuel Cell (PEMFC), Phosphoric Acid Fuel Cell (PAFC), Molten Carbonate Fuel Cell (MCFC) and Solid Oxide Fuel Cell (SOFC). Each of them has advantages with their specific features according to usage areas. PEMFC is used more widely today than other fuel cells. With its high voltage, current and power density, low pressure operation, corrosion-resistant electrolyte usage, tolerance to pressure change, simple structure, low temperature operation, portable usage, it is more accurate choice than the other fuel cells with its advantages $[2,6,7]$.

Metal, non-metal and composite materials are used as material of end plates in fuel cells. Composite materials are also preferred in fuel cells due to their light weight, corrosion resistance and high mechanical properties [8]. There are studies with composite on bipolar flow plates and end plate 
plates. However, there are many studies on bipolar flow plates, few studies on end plates [9-12].

Fracture energy is an important case to decide safe conditions of material. When different loads are applied to specimen, it is significant to determine what kind of breakage may occur. There are three fracture modes which are mode I (opening), mode II (sliding shear) and mode III (tearing) [13]. These modes are evaluated by using methods for mode I Double Cantilever Beam (DCB), for mode II End Notched Flexure (ENF), for mode III Crack Rail Shear (CRS) and Asymmetric Double Cantilever Beam (ADCB), Asymmetric Tapered Double Cantilever Beam (ATDCB), Crack Lap Shear (CLS) and Single Leg Bending (SLB) methods are used to calculate fracture energy of material. To compute fracture energy of mixed mode which is combining load form of mode I and mode II, different methods are required. The use of different test cases can lead to difficult test conditions and results. To carry out mixed mode conditions to test material, Arcan specimen is efficient due to facility observation of different mixed modes [14-16].

In this study, numerical analysis of fracture energy for different materials was compared for selected end plate of PEMFC. Strain energy release rates were calculated numerically by using Arcan specimen for mode I, mode II and mixed modes. To decide appropriate material for PEMFC end plate, the fracture energy results were compared for wide range of material system.

\section{DESCRIPTION OF SET-UP}

Fuel cells are devices that convert chemical energy to electrical energy directly. PEMFC is common type fuel cell and it contains membrane, gas diffusion layer (GDL), catalyst layer (CL), bipolar flow plate (BFP) or bipolar plate and end plate. Membrane, GDL and CL are joined together to form a membrane electrode assembly (MEA). Parts of PEMFC are shown in Figure 1. A single fuel cell consists of a MEA and two BFP producing about $1.2 \mathrm{~V}$ [17]. This assembly of cell is called a fuel cell stacks. For more voltage, more cells are stacked [18]. Stacks are clamped between two end plates to hold them together $[10,19]$.

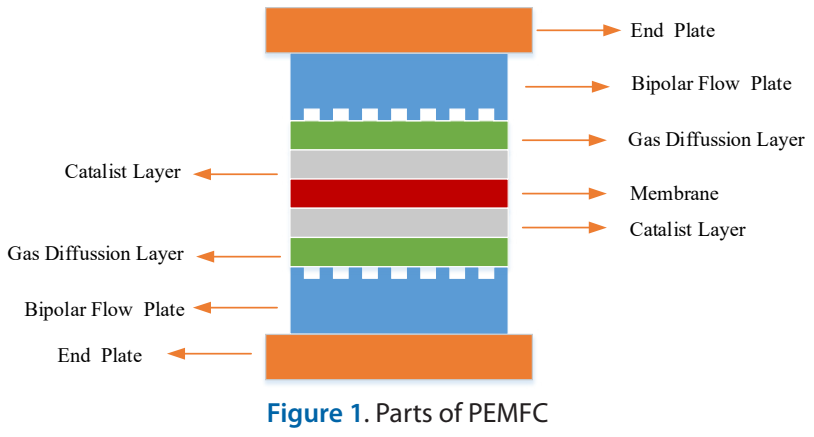

In PEMFC fuel cells, an end plate is used to hold the stacks together. Generally end plates have to be possessed of low density, electrochemical stability, high mechanical strength and stiffness and electrical insulation. So, metal, non-metals and composites materials can be used as fuel cell end plate
[19-21]. End plate materials are used with different thickness and design by changing their material properties. Yu et. al. [10] determined size of composite plate as given in Figure 2. Besides they set down thickness of composite material as 10 $\mathrm{mm}$ for stainless steel and $15 \mathrm{~mm}$ for composite material.

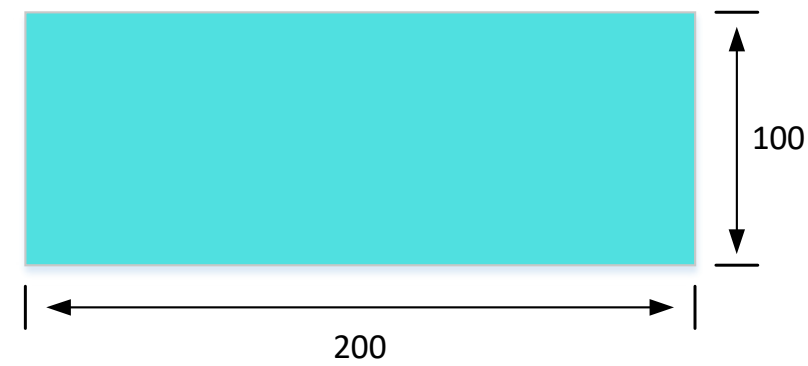

Figure 2. Size of end plate

Fuel cell stacks are combined with end plates, so it has to have high flexural stiffness to keep together all parts in ideal conditions. If there is too much contact pressure, this condition can compress gas diffusion layer (GDL) and can change GDL porosity. Besides, gas and water flow will not transfer from PEMFC flow channels sufficiently. However, if there is little contact pressure, this can cause high contact resistance between back of GDL and bipolar flow plates (BFP) that can reduce performance of fuel cell. Hence, PEMFC end plate should high flexural stiffness. If it has low flexural stiffness, it may yield a non-uniform contact pressure in the whole plate as given in Figure 3 [10].

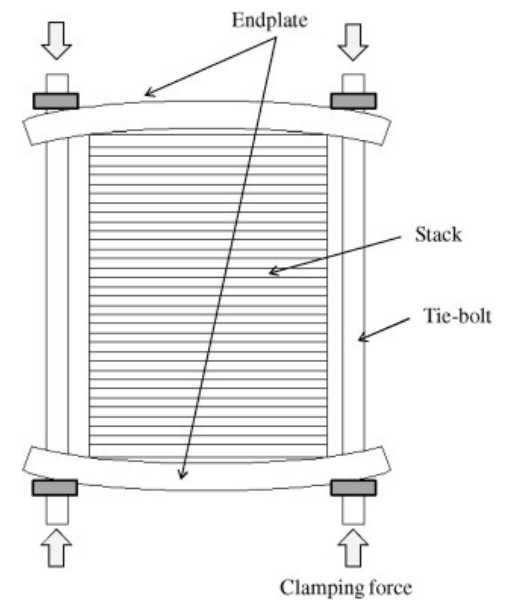

Figure 3. Deflection of PEMFC End Plate [10]

Composite materials are combined with two or more components therefore they may have different mechanical properties at each direction. When different loads are applied to specimen by varying angles, it is important to determine what kind of failure may occur. Also, fracture energy is important in order to decide safe conditions of material [13, 22].

\section{THEORITICAL BACKGROUND}

The fracture energy of material is investigated by using linear elastic fracture mechanics which is used to calculate the strain energy release rate at the crack tip [23]. It is a useful tool for composite material cracks when the specimen is orthotropic material [15]. The Generalized Hooke's law is 
given in the following equation $[24,25]$.

$$
\left(\begin{array}{c}
\varepsilon_{x} \\
\varepsilon_{y} \\
\varepsilon_{z} \\
\gamma_{y z} \\
\gamma_{x z} \\
\gamma_{x y}
\end{array}\right)=\left(\begin{array}{llllll}
a_{11} & a_{12} & a_{13} & a_{14} & a_{15} & a_{16} \\
a_{21} & a_{22} & a_{23} & a_{24} & a_{25} & a_{26} \\
a_{31} & a_{32} & a_{33} & a_{34} & a_{35} & a_{36} \\
a_{41} & a_{42} & a_{43} & a_{44} & a_{45} & a_{46} \\
a_{51} & a_{52} & a_{53} & a_{54} & a_{55} & a_{56} \\
a_{61} & a_{62} & a_{63} & a_{64} & a_{65} & a_{66}
\end{array}\right)\left(\begin{array}{c}
\sigma_{x} \\
\sigma_{y} \\
\sigma_{z} \\
\tau_{y z} \\
\tau_{x z} \\
\tau_{x y}
\end{array}\right)
$$

Expressions of letters are strain $(\varepsilon)$, normal stress $(\sigma)$, shear stress $(\tau)$, shearing strain $(\gamma)$ and constants $\left(a_{i j}\right)$. Elastic constants are given as the following relationships.

$$
\begin{aligned}
& a_{11}=\frac{1}{E_{x}} \quad a_{22}=\frac{1}{E_{y}} \quad a_{33}=\frac{1}{E_{z}} \\
& a_{44}=\frac{1}{G_{y z}} \quad a_{55}=\frac{1}{G_{x z}} \quad a_{66}=\frac{1}{G_{x y}} \quad a_{12}=a_{21}=-\frac{v_{x y}}{E_{x}}=-\frac{v_{y x}}{E_{y}} \\
& a_{13}=a_{31}=-\frac{v_{x z}}{E_{x}}=-\frac{v_{z x}}{E_{z}} \quad a_{23}=a_{32}=-\frac{v_{y z}}{E_{y}}=-\frac{v_{z y}}{E_{z}}
\end{aligned}
$$

Where $E_{x}, E_{y}, E_{z}$ are elastic modulus in direction of $\mathrm{x}, \mathrm{y}, \mathrm{z}$. $G_{x y}, G_{x y}, G_{y z}$ are shear modulus in each plane and $\mathbf{U}_{x y}, \mathbf{U}_{y x}, \mathrm{U}_{y z}$ are Poisson's ratio.

In case of a thin plate, principal axes are in xy plane and assuming conditions are given as:

$$
\sigma_{z}=\tau_{y z}=\tau_{x z}=0
$$

If the Eq. (3) assumptions are written in Eq. (1), then equation is turned into Eq. (4).

$$
\left(\begin{array}{l}
\stackrel{a}{x}_{x} \\
\check{a}_{y} \\
\gamma_{x y}
\end{array}\right)=\left(\begin{array}{lll}
a_{11} & a_{12} & a_{16} \\
a_{12} & a_{22} & a_{26} \\
a_{16} & a_{26} & a_{66}
\end{array}\right)\left(\begin{array}{l}
\sigma_{x} \\
\sigma_{y} \\
\tau_{x y}
\end{array}\right)
$$

Where $\sigma_{x}, \sigma_{y}, T_{x y}$ are plane stresses and $\varepsilon_{x^{\prime}}, \varepsilon_{y^{\prime}}, Y_{x y}$ are plane strains.

The another assumptions are given in Eq. (5)

$$
\begin{aligned}
& \varepsilon_{z}=\gamma_{y z}=\gamma_{x z}=0 \\
& \sigma_{z}=\frac{-\left(a_{13} \sigma_{x}+a_{23} \sigma_{y}+a_{13} \tau_{x y}\right)}{a_{33}}
\end{aligned}
$$

$$
\left(\begin{array}{l}
\stackrel{\circ}{a}_{x} \\
\stackrel{a}{y}_{y} \\
\gamma_{x y}
\end{array}\right)=\left(\begin{array}{lll}
b_{11} & b_{12} & b_{16} \\
b_{12} & b_{22} & b_{26} \\
b_{16} & b_{26} & b_{66}
\end{array}\right)\left(\begin{array}{l}
\sigma_{x} \\
\sigma_{y} \\
\tau_{x y}
\end{array}\right)
$$

Where the terms of constants $b_{i j}$ are defined in terms of the following nonzero entries $a_{i j}$ of the compliance matrix:

$$
\begin{aligned}
& b_{i j}=a_{i j}-\frac{a_{i 3} a_{j 3}}{a_{33}} \quad(\mathrm{i}, \mathrm{j}=1,2,4,5,6) \\
& a_{16}=a_{26}=a_{36}=a_{45}=0^{\prime} \quad b_{16}=b_{26}=0, \\
& b_{11}=\frac{a_{11} a_{33}-a_{13}^{2}}{a_{33}}, b_{12}=\frac{a_{12} a_{33}-a_{13} a_{23}}{a_{33}}, \\
& b_{22}=\frac{a_{22} a_{33}-a_{23}^{2}}{a_{33}}, b_{66}=\frac{a_{66} a_{33}-a_{36}^{2}}{a_{33}}
\end{aligned}
$$

The strain energy release rates are calculated by Eq. (10). Where $G_{I}$ and $G_{I I}$ are mode I and mode II strain energy release rates, $E_{I}$ and $E_{I I}$ effective moduli, $K_{I}$ and $K_{I I}$ are mode I and mode II stress intensity factors, respectively.

$$
\begin{aligned}
& G_{I}=\frac{K_{I}^{2}}{E_{I}}, G_{I I}=\frac{K_{I I}^{2}}{E_{I I}} \\
& E_{I}=\sqrt{\frac{2}{a_{11} a_{22}}} \frac{1}{\sqrt{\left(\left(\sqrt{\frac{a_{22}}{a_{11}}}\right)+\frac{2 a_{12}+a_{66}}{2 a_{11}}\right)}} \\
& E_{I I}=\frac{\sqrt{2}}{a_{11}} \frac{1}{\sqrt{\left(\left(\sqrt{\frac{a_{22}}{a_{11}}}\right)+\frac{2 a_{12}+a_{66}}{2 a_{11}}\right)}} \text { (for plane stress); } \\
& E_{I}=\sqrt{\frac{2}{b_{11} b_{22}}} \frac{1}{\sqrt{\left(\left(\sqrt{\frac{b_{22}}{b_{11}}}\right)+\frac{2 b_{12}+b_{66}}{2 b_{11}}\right)}} \\
& E_{I I}=\frac{\sqrt{2}}{b_{11}} \frac{1}{\sqrt{\left(\left(\sqrt{\frac{b_{22}}{b_{11}}}\right)+\frac{2 b_{12}+b_{66}}{2 b_{11}}\right)}} \text { (for plane strain) }
\end{aligned}
$$

\section{FINITE ELEMENT MODELING OF MIXED MODE FRACTURE}

Finite element analysis was carried out by using J-integral method for numerical calculation. Arcan specimen is applied constant $1000 \mathrm{~N}$ load by using Abaqus. Arcan Specimen modelling in Abaqus is shown in Figure 4. The model was created using eight nodes and collapsed elements of the model (CPE8RH). The mesh was focused around the crack tip, and linear elastic finite element analysis was performed under the plane strain conditions.

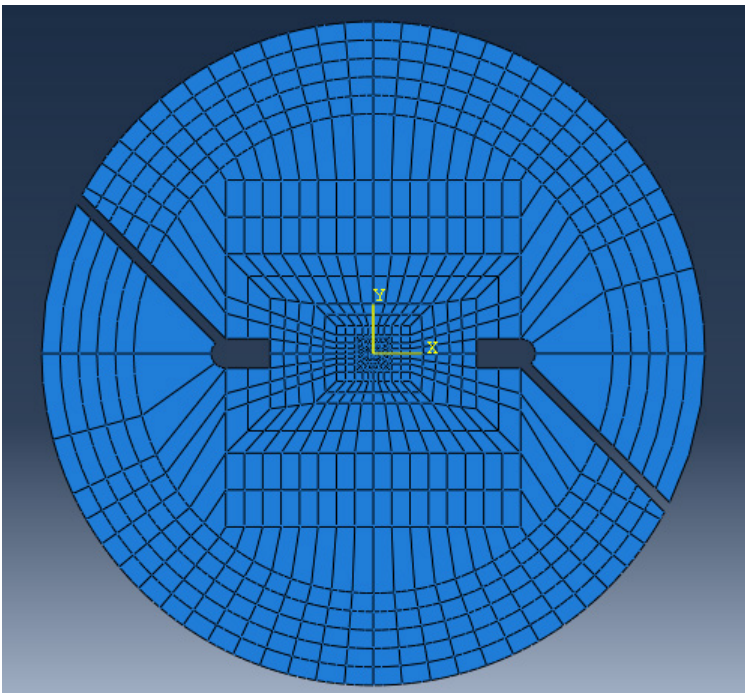

Figure 4. Arcan Specimen modelling in Abaqus

Fracture behaviors of selected materails were investigated numerically by using $2 \mathrm{D}$ arcan specimen under different loading conditions. The typical loading angles of mode I $\left(0^{\circ}\right)$, mixed mode $\left(45^{\circ}\right)$ and mode II $\left(90^{\circ}\right)$ are shown in Figure 5.

Composite materials show distinct characteristics in each direction, but metal and ceramic materials have the same properties due to homogeneous sturucture. Therefore, all materials have different properties so they give different starin energy release rate results under mode I, mode II and 


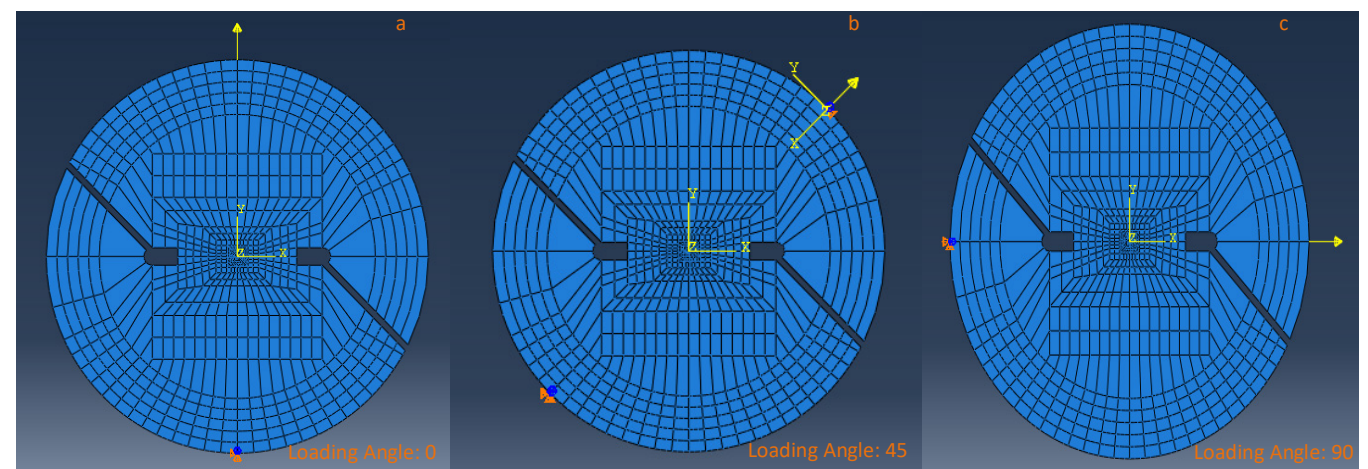

Figure 5. Arcan specimen under different loading angle, (a) mode I loading condition, (b) mixed mode loading condition and (c) mode II loading condition

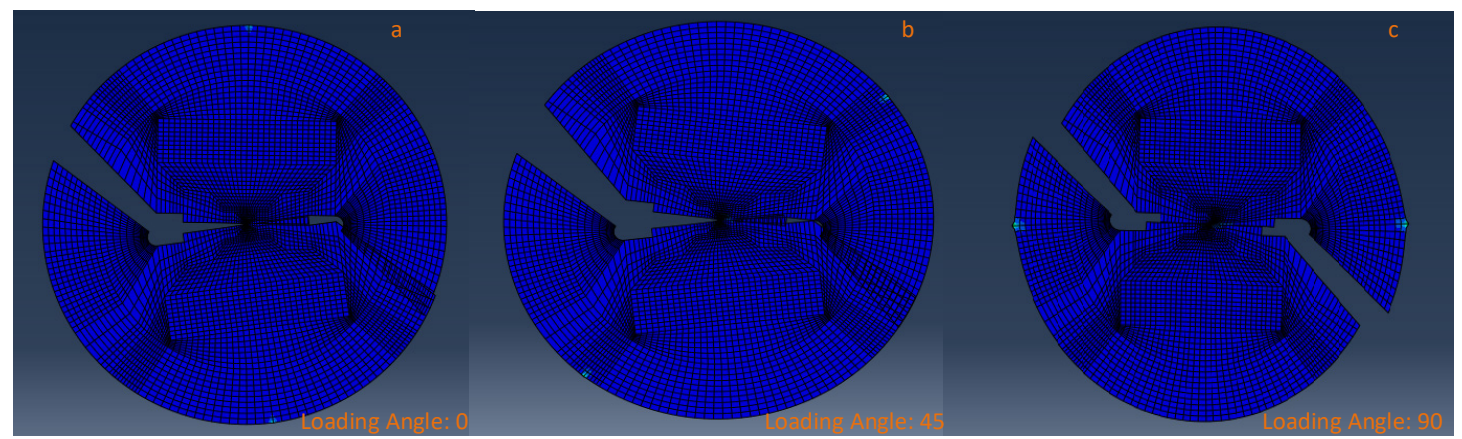

Figure 6. Arcan specimen numerical deformation results, (a) mode I fracture result, (b) mixed mode fracture result and (c) mode II fracture result

Table 1. Elastic property of materials under investigation.

\begin{tabular}{|c|c|c|c|c|c|c|c|c|c|}
\hline Material & $\begin{array}{c}\mathrm{E}_{1} \\
{[\mathrm{GPa}]}\end{array}$ & $\begin{array}{c}\mathrm{E}_{2} \\
{[\mathrm{GPa}]}\end{array}$ & $\begin{array}{c}\mathrm{E}_{3} \\
{[\mathrm{GPa}]}\end{array}$ & $\begin{array}{c}\mathrm{G}_{12} \\
{[\mathrm{GPa}]}\end{array}$ & $\begin{array}{c}\mathrm{G}_{13} \\
{[\mathrm{GPa}]}\end{array}$ & $\begin{array}{c}\mathrm{G}_{23} \\
{[\mathrm{GPa}]}\end{array}$ & $\mathrm{U}_{12}$ & $\mathrm{U}_{13}$ & $\mathrm{U}_{23}$ \\
\hline Steel [28] & 207 & 207 & 207 & 79.6 & 79.6 & 79.6 & 0.30 & 0.30 & 0.30 \\
\hline Titanium [29] & 110 & 110 & 110 & 42 & 42 & 42 & 0.31 & 0.31 & 0.31 \\
\hline Aluminum [28] & 72 & 72 & 72 & 27 & 27 & 27 & 0.33 & 0.33 & 0.33 \\
\hline Boron-epoxy [29] & 193.06 & 18.62 & 18.62 & 5.52 & 5.52 & 7.76 & 0.21 & 0.21 & 0.2 \\
\hline UD Gr-epoxy [29] & 132.7 & 8.83 & 8.83 & 4.76 & 4.76 & 3.40 & 0.36 & 0.36 & 0.30 \\
\hline CP Gr-epoxy [29] & 71.2 & 71.2 & 8.83 & 4.76 & 4.0 & 4.0 & 0.04 & 0.32 & 0.32 \\
\hline Kevlar-KM2 [35] & 84 & 1.34 & 1.34 & 24.4 & 24.4 & 0.54 & 0.0095 & 0.0095 & 0.24 \\
\hline Glass-Polyester [27] & 47.92 & 13.94 & 13.94 & 5.21 & 5.21 & 20.9 & 0.27 & 0.27 & 0.33 \\
\hline CFRP [26] & 138 & 10 & 10 & 6 & 6 & 3.7 & 0.27 & 0.27 & 0.45 \\
\hline Aluminum6061 [34] & 68.9 & 68.9 & 68.9 & 25.9 & 25.9 & 25.9 & 0.33 & 0.33 & 0.33 \\
\hline AISiC [30] & 150 & 150 & 150 & 57.7 & 57.7 & 57.7 & 0.3 & 0.3 & 0.3 \\
\hline T300 [31] & 135 & 9.26 & 9.26 & 6.15 & 6.15 & 3.07 & 0.32 & 0.32 & 0.51 \\
\hline Ceramic [32] & 96 & 96 & 96 & 37.2 & 37.2 & 37.2 & 0.29 & 0.29 & 0.29 \\
\hline GFRP [33] & 31.22 & 31.62 & 24.61 & 9.05 & 9.25 & 9.31 & 0.22 & 0.30 & 0.24 \\
\hline
\end{tabular}

mixed loading conditions. Arcan Specimen numerical deformation results are given in Figure 6. It can be seen that the material undergoes different deformation in each mode.

\section{RESULTS AND DISCUSSION}

In this study, the values of strain energy release rates for mode I, mode II, and mixed mode were obtained by using 2D Arcan specimen model by changing loading angles. Constant value of the load $1000 \mathrm{~N}$ is applied to different materials in order to compare the results and investigate the loading angle variations of fracture energy parameters. The end plate should be assembled with ideal clamping pressure. That can be affected performance of PEMFC parts. Particularly, MEA performance depends on change of clamping pressure. Therefore, PEMFC efficiency is affected from changing the clamping pressure. The end plate provides de- sired working conditions so decision of convenient material is significant. Besides, the end plate should have low density, electrochemical stability, high rigidity, insulating property and corrosion resistance [20, 21].

Generally metals, non-metals and composite materials can be used as fuel cell end plate [19, 20]. In this study, steel, titanium, aluminum, boron-epoxy, UD graphite-epoxy, CP graphite-epoxy, kevlar-KM2, glass-polyester, CFRP (Carbon Fiber Reinforced Polymer), aluminum6061, AlSiC (Aluminum Silicon Carbide), T300 (T300/976 UD tape), ceramic and GFRP (Glass Fiber Reinforced Polymer) are selected as end plate of PEMFC material system. The elastic properties of all materials used in numerical analysis are listed in the Table 1 [26-35]. In this paper, strain eneregy release rate of the 14 different materials were investigated by numerical analysis of Arcan specimen. Additionally, their fractu- 
re energy were obtained in order to make decision about the most appropriate material as end plate. To obtain strain energy release rates of materials, $1000 \mathrm{~N}$ load is applied at pure mode I, mixed mode with $15^{\circ}$ intervals and pure mode II conditions.

Values of mode I strain energy release rates versus loading angle for various materials are shown in Table 2 and Figure 7. As it can be seen, for all materials used in this investigation the mode I fracture energy decreases as the mode II loading contribution increases. The mode I fracture energy has the maximum value for the Kevlar-KM2 and the minimum value for the steel among the studied materials under all loading angle conditions.

Table 2. Mode I fracture energy $G_{I}\left(\mathrm{~J} / \mathrm{m}^{2}\right)$ for various materials under different loading angles.

\begin{tabular}{|c|c|c|c|c|c|c|c|}
\hline \multirow{2}{*}{ Material } & \multicolumn{7}{|c|}{ Loading angle (Degrees) } \\
\cline { 2 - 8 } & $\mathbf{0}^{\circ}$ & $\mathbf{1 5}^{\circ}$ & $\mathbf{3 0 ^ { \circ }}$ & $\mathbf{4 5}^{\circ}$ & $\mathbf{6 0}^{\circ}$ & $\mathbf{7 5}^{\circ}$ & $\mathbf{9 0 ^ { \circ }}$ \\
\hline Kevlar-KM2 & 528.92 & 493.31 & 396.58 & 264.27 & 132.13 & 35.40 & 0 \\
\hline UD Graphite-epoxy & 227.02 & 211.80 & 170.28 & 113.57 & 56.76 & 15.21 & 0 \\
\hline CFRP & 179.47 & 167.50 & 134.66 & 89.76 & 44.88 & 12.03 & 0 \\
\hline T300 & 176.70 & 164.86 & 132.52 & 88.39 & 44.18 & 11.84 & 0 \\
\hline Glass-Polyester & 174.75 & 163.08 & 131.09 & 87.39 & 43.69 & 11.70 & 0 \\
\hline Boron-epoxy & 144.63 & 134.97 & 108.51 & 72.35 & 36.18 & 9.70 & 0 \\
\hline GFRP & 92.63 & 86.40 & 69.47 & 46.31 & 23.15 & 6.20 & 0 \\
\hline CP Graphite-epoxy & 82.37 & 76.86 & 61.79 & 41.19 & 20.59 & 5.51 & 0 \\
\hline Aluminum6061 & 35.77 & 33.41 & 26.86 & 17.92 & 8.97 & 2.40 & 0 \\
\hline Aluminum & 34.27 & 31.98 & 25.72 & 17.15 & 8.58 & 2.30 & 0 \\
\hline Ceramic & 26.46 & 24.69 & 19.85 & 13.25 & 6.63 & 1.78 & 0 \\
\hline Titanium & 22.81 & 21.28 & 17.22 & 11.42 & 5.72 & 1.53 & 0 \\
\hline AlSiC & 16.88 & 15.75 & 12.67 & 8.45 & 4.23 & 1.13 & 0 \\
\hline Steel & 12.27 & 11.45 & 9.21 & 6.15 & 3.08 & 0.82 & 0 \\
\hline
\end{tabular}

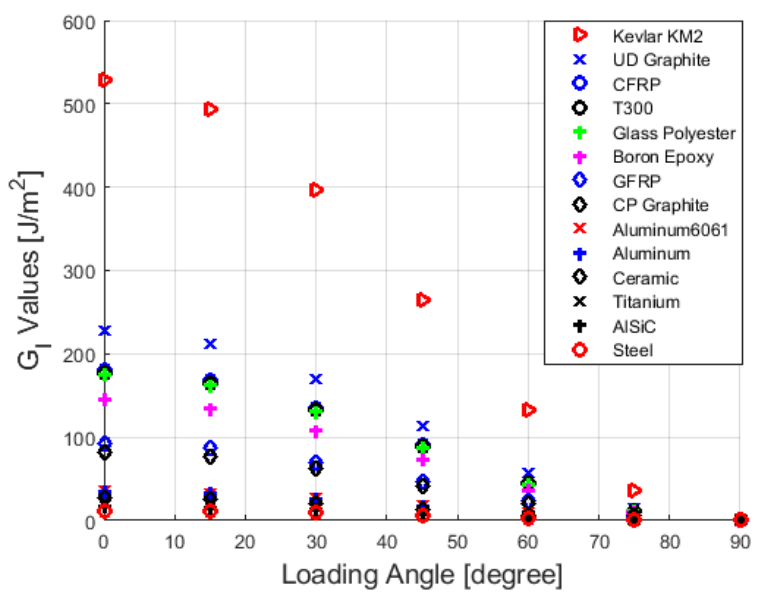

Figure 7. $G$, fracture energy versus loading angle graph.

Table 3 and Figure 8 show the mode II fracture energy of the materials system under study. It reveals that the mode II fracture energy has its highest value at 90 degrees loading angle and increases as the mode II loading contribution increases for all investigated materials. For all materials under study in this investigation, Glass-Polyester has the highest $G_{I I}$ fracture energy value; on the other hand the $G_{I I}$ value of steel has the lowest among the materials.

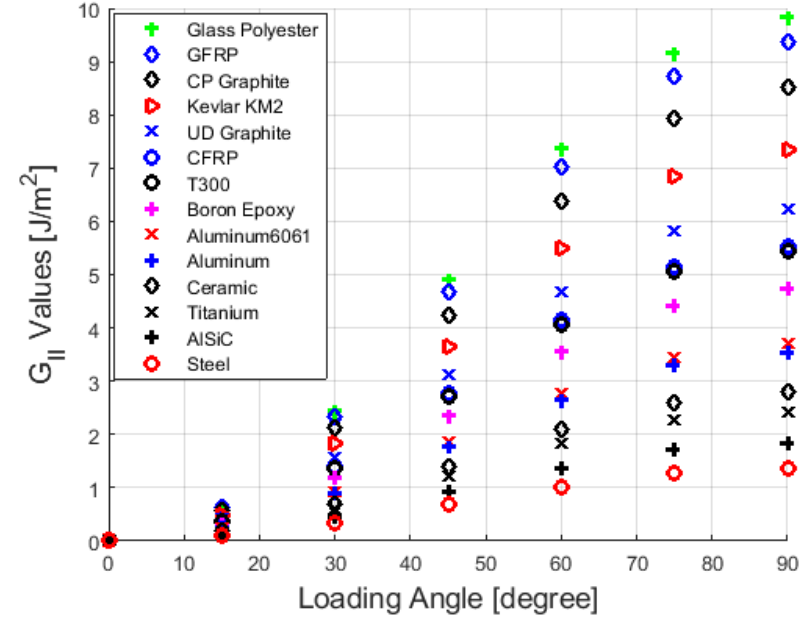

Figure 8. $G_{\|}$fracture energy versus loading angle graph

Table 3. Mode II fracture energy $G_{\| I}\left(\mathrm{~J} / \mathrm{m}^{2}\right)$ for various materials under different loading angles.

\begin{tabular}{|c|c|c|c|c|c|c|c|}
\hline \multirow{2}{*}{ Material } & \multicolumn{7}{|c|}{ Loading angle (Degrees) } \\
\cline { 2 - 8 } & $\mathbf{0}^{\circ}$ & $\mathbf{1 5}$ & $\mathbf{3 0 ^ { \circ }}$ & $\mathbf{4 5}^{\circ}$ & $\mathbf{6 0}^{\circ}$ & $\mathbf{7 5}^{\circ}$ & $\mathbf{9 0 ^ { \circ }}$ \\
\hline Glass-Polyester & 0 & 0.66 & 2.46 & 4.92 & 7.38 & 9.18 & $\mathbf{9 . 8 3}$ \\
\hline GFRP & 0 & 0.63 & 2.34 & 4.68 & 7.02 & 8.72 & 9.36 \\
\hline CP Graphite-epoxy & 0 & 0.57 & 2.12 & 4.25 & 6.37 & 7.93 & 8.52 \\
\hline Kevlar-KM2 & 0 & 0.48 & 1.83 & 3.66 & 5.50 & 6.84 & 7.34 \\
\hline UD Graphite-epoxy & 0 & 0.42 & 1.56 & 3.12 & 4.68 & 5.81 & 6.23 \\
\hline CFRP & 0 & 0.37 & 1.38 & 2.77 & 4.15 & 5.15 & 5.53 \\
\hline T300 & 0 & 0.36 & 1.36 & 2.71 & 4.07 & 5.07 & 5.43 \\
\hline Boron-epoxy & 0 & 0.32 & 1.18 & 2.37 & 3.56 & 4.42 & 4.73 \\
\hline Aluminum6061 & 0 & 0.25 & 0.93 & 1.85 & 2.77 & 3.45 & 3.70 \\
\hline Aluminum & 0 & 0.24 & 0.89 & 1.78 & 2.66 & 3.31 & 3.55 \\
\hline Ceramic & 0 & 0.19 & 0.70 & 1.40 & 2.09 & 2.60 & 2.79 \\
\hline Titanium & 0 & 0.16 & 0.61 & 1.21 & 1.82 & 2.26 & 2.42 \\
\hline AlSiC & 0 & 0.12 & 0.46 & 0.92 & 1.37 & 1.71 & 1.83 \\
\hline Steel & 0 & 0.14 & 0.34 & 0.68 & 1.02 & 1.27 & 1.36 \\
\hline
\end{tabular}

The total strain energy release rates obtained by $G_{T}=G_{I}+G_{I I}$ in different loading angles are shown for the all materials in Table 4 and Figure 9. Total strain energy release under mixed-mode loading conditions changes with the loading angle. In pure mode I loading angle, they have the highest $G_{T}$ value for all materials. As loading angle increases towards mode II conditions its value decreases. As compared for all the materials, Kevlar-KM2 has the highest $G_{T}$ value in pure mode I, pure mode II and all mixed mode conditions. On the other hand, $G_{T}$ of steel has the lowest value among all material in mode I, mode II and mixed mode loadings.

Table 5 summarizes the fracture energy values of the mode I $\left(G_{I}\right)$, the mode II $\left(G_{I I}\right)$, the total $\left(G_{T}\right)$, the fracture toughness $\left(G_{I C}\right)$, and the ratio $\left(G_{I C} / G_{I}\right)$ for all materials system under investigation in this study. The fracture toughness values of the materials are obtained from the literature. It can be seen that values of $G_{I}$ and $G_{T}$ of kevlar-KM2 are higher among the other materials. However, aluminum has the highest value of $G_{I C}$ among all the materials in the table. Furthermore, $G_{I I}$ of glass-polyester has the highest value among the materials. Meanwhile, the fracture energy ratio $\left(G_{I C} / G_{I}\right)$ of steel is supreme among the selected metallic materials so it is the best choice when other criteria like density are not 
Table 4. Total fracture energy $G_{T}\left(\mathrm{~J} / \mathrm{m}^{2}\right)$ for various materials under different loading angles.

\begin{tabular}{|c|c|c|c|c|c|c|c|}
\hline \multirow{2}{*}{ Material } & \multicolumn{7}{|c|}{ Loading angle (Degrees) } \\
\cline { 2 - 9 } & $\mathbf{0}^{\circ}$ & $\mathbf{1 5}^{\circ}$ & $\mathbf{3 0}^{\circ}$ & $\mathbf{4 5 ^ { \circ }}$ & $\mathbf{6 0}^{\circ}$ & $\mathbf{7 5}^{\circ}$ & $\mathbf{9 0}^{\circ}$ \\
\hline Kevlar-KM2 & 528.92 & 493.79 & 398.41 & 267.93 & 137.63 & 42.24 & 7.34 \\
\hline UD Graphite-epoxy & 227.02 & 212.22 & 171.84 & 116.69 & 61.44 & 21.02 & 6.23 \\
\hline CFRP & 179.47 & 167.87 & 136.04 & 92.53 & 49.03 & 17.18 & 5.53 \\
\hline T300 & 176.67 & 165.22 & 133.88 & 91.10 & 48.25 & 16.91 & 5.43 \\
\hline Glass-Polyester & 174.75 & 163.74 & 133.55 & 92.31 & 51.07 & 20.89 & 9.83 \\
\hline Boron-epoxy & 144.63 & 135.29 & 109.69 & 74.72 & 39.74 & 14.12 & 4.73 \\
\hline GFRP & 92.63 & 87.03 & 71.81 & 50.99 & 30.17 & 14.92 & 9.36 \\
\hline CP Graphite-epoxy & 82.37 & 77.43 & 63.91 & 45.44 & 26.97 & 13.44 & 8.52 \\
\hline Aluminum6061 & 35.79 & 33.66 & 27.79 & 19.77 & 11.74 & 5.85 & 3.70 \\
\hline Aluminum & 34.27 & 32.22 & 26.61 & 18.93 & 11.24 & 5.61 & 3.55 \\
\hline Ceramic & 26.46 & 24.88 & 20.55 & 14.65 & 8.72 & 4.38 & 2.79 \\
\hline Titanium & 22.81 & 21.44 & 17.83 & 12.63 & 7.54 & 3.79 & 2.42 \\
\hline AISiC & 16.88 & 15.87 & 13.13 & 9.37 & 5.60 & 2.84 & 1.83 \\
\hline Steel & 12.27 & 11.59 & 9.55 & 6.83 & 4.1 & 2.09 & 1.36 \\
\hline
\end{tabular}

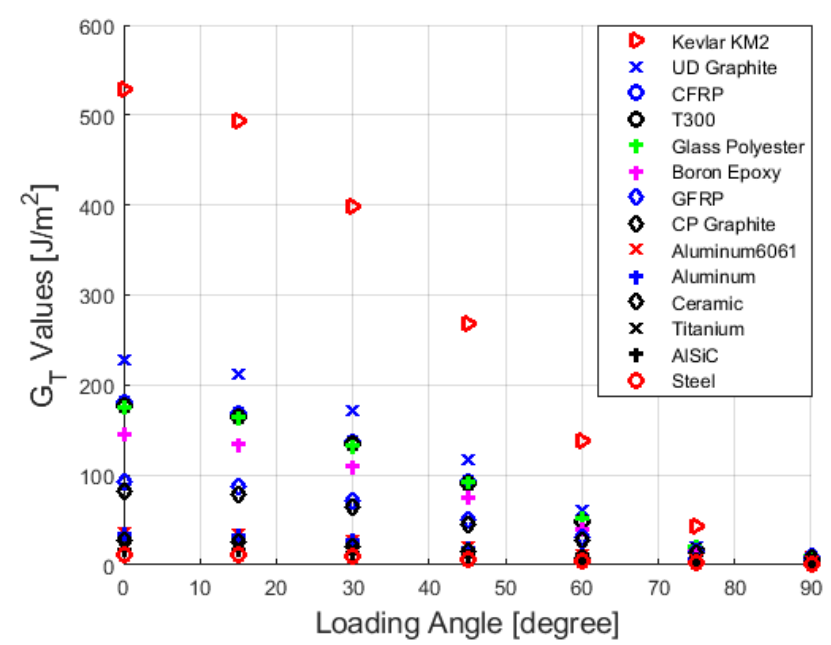

Figure 9. $G_{T}$ fracture energy versus loading angle graph.

Table 5. Strain energy release rates versus fracture toughness properties.

\begin{tabular}{|c|c|c|c|c|c|}
\hline Material & $G_{I}$ & $G_{\|}$ & $G_{T}$ & $G_{K C}$ & $G_{K C} / G_{1}$ \\
\hline Steel & 12.27 & 1.36 & 13.63 & $9835[39]$ & 801.55 \\
\hline Titanium & 22.81 & 2.42 & 25.23 & $12180[39]$ & 533.86 \\
\hline Aluminum & 34.27 & 3.54 & 37.81 & $14391[39]$ & 420.00 \\
\hline Aluminum6061 & 35.77 & 3.70 & 39.47 & $10877[34]$ & 304.08 \\
\hline AlSiC & 16.88 & 1.83 & 18.71 & $480.54[40]$ & 28.47 \\
\hline CP Graphite-epoxy & 82.37 & 8.52 & 90.89 & $1500[25]$ & 18.21 \\
\hline Kevlar-KM2 & 528.92 & 7.34 & 536.26 & $8717.7[35]$ & 16.48 \\
\hline GFRP & 92.63 & 9.36 & 101.99 & $1440[33]$ & 15.54 \\
\hline Ceramic & 26.46 & 2.79 & 29.25 & $152[41]$ & 5.74 \\
\hline UD Graphite-epoxy & 227.02 & 6.23 & 233.25 & $800[29]$ & 3.52 \\
\hline Glass-Polyester & 174.75 & 9.83 & 184.58 & $496[42]$ & 2.84 \\
\hline CFRP & 179.47 & 5.53 & 185.00 & $436[26]$ & 2.43 \\
\hline Boron-epoxy & 144.63 & 4.73 & 149.36 & $328[43]$ & 2.27 \\
\hline T300 & 176.70 & 5.43 & 182.13 & $165[44]$ & 0.93 \\
\hline
\end{tabular}

considered. Additionally, other parameters like density of material should be considered in order to consider for proper material selection of end plate. Composite materials with the advantage of strength and hardness along with lightness have proven their use through many applications in various fields. In this investigation, CP graphite-epoxy, kevlar-KM2 and GFRP with densities of $1.60 \mathrm{~g} / \mathrm{cc}, 1.45 \mathrm{~g} / \mathrm{cc}$ and $2.20 \mathrm{~g} /$ $\mathrm{cc}$, respectively [36-38], were found to ensure the maximum value of $G_{I C} / G_{I}$ among studied composite materials. In this study, a numerical attempt was made to explain some of the important issues related to the fracture energy of the selected material used in the end plates of the fuel cell. Due to the importance of the issue, there is still significant activity in this area. Therefore, some future research in this area may be required to perform parallel design exercises using numerical and experimental fracture approaches on commonly used materials as end plate material.

\section{CONCLUSION}

In this paper, PEMFC end plates materials and their strain energy release rates were investigated by numerical analysis of Arcan specimen under different loading conditions. Firstly, stress intensity factors are obtained for each material by finite element analyzing Arcan specimen using Abaqus package program finite element and fracture energy of materials in mode I, mode II and mixed mode conditions were calculated. According to the results, for loading angles close to mode I condition, mode I fracture was dominant. For loading angles close to mode II condition, mode II strain energy release rates became dominant. Besides, it was concluded that the total strain energy release rate under mixed mode loading conditions decreases with the increasing loading angle. Among the studied metals, steel, titanium and aluminum were found to have superior fracture energy values. Various applications of composite materials in primary and secondary structures have made them as a suitable alternative to metal materials. Composite materials with strength and stiffness combined with lightness have proven their application through many applications in various fields. Due to their importance in engineering applications, in this investigation, CP graphite-epoxy, kevlar-KM2 and GFRP were confirmed to warrant the appropriate fracture resistance among studied composite materials. Kevlar-KM2 has lower density and higher fracture toughness values than CP graphite-epoxy and GFRP. Therefore, kevlar-KM2 was found as an appropriate composite material for PEMFC end plate by considering fracture energy and density of the material parameters.

\section{REFERENCES}

[1] Ural, Z., Gencoglu, M.T., (2010). Mathematical Models of PEM Fuel Cells. 5th International Ege Energy Symposium and Exhibition (IEESE-5). (June): 27-30.

[2] Giorgi, L., \& Leccese, F. (2013). Fuel cells: Technologies and applications. The Open Fuel Cells Journal, 6(1): 1-20. doi: 10.2174/1875932720130719001.

[3] Scott, K., Shukla, A.K., (2004). Polymer electrolyte membrane fuel cells: Principles and advances. Reviews in Environmental Science and Biotechnology. 3(3): 273-80. doi: 10.1007/s11157-004-6884-z.

[4] Vishnyakov, V.M., (2006). Proton exchange membrane fuel cells. Vacuum. 80(10): 1053-65. doi: 10.1016/j.vacuum.2006.03.029.

[5] Habibi, A., Mousavi, N., Mohammadi, M., Farahmand, S. (2019). The Performance of Types of Fuel Cell: Energy Generation. International Journal of Engineering Science and Application, 3(3), 142-150. 
[6] Dhand, A., (2017). Advances in Materials for Fuel Cell TechnologiesA Review. International Journal for Research in Applied Science and Engineering Technology. V(IX): 1672-82. doi: 10.22214/ijraset.2017.9243.

[7] Perry, M.L., Fuller, T.F., (2002). A Historical Perspective of Fuel Cell Technology in the 20th Century. Journal of The Electrochemical Society. 149(7): 59-67. doi: 10.1149/1.1488651.

[8] Baroutaji, A., Carton, J.G., Sajjia, M., Olabi, A.G., (2016). Materials in PEM Fuel Cells. Elsevier Ltd.

[9] Tamilarasan, U., Karunamoorthy, L., Palanikumar, K., (2015). Mechanical properties evaluation of the carbon fibre reinforced aluminium sandwich composites. Materials Research. 18(5): 1029-37. doi: 10.1590/1516-1439.017215.

[10] Yu, H.N., Kim, S.S., Suh, J. Do., Lee, D.G., (2010). Composite endplates with pre-curvature for PEMFC (polymer electrolyte membrane fuel cell). Composite Structures. 92(6): 1498-503. doi: 10.1016/j.compstruct.2009.10.023.

[11] Hermann, A., Chaudhuri, T., Spagnol, P., (2005). Bipolar plates for PEM fuel cells: A review. International Journal of Hydrogen Energy. 30(12): 1297-302. doi: 10.1016/j.ijhydene.2005.04.016.

[12] Wilberforce, T., El Hassan, Z., Ogungbemi, E., ljaodola, O., Khatib, F.N., Durrant, A., et al., (2019). A comprehensive study of the effect of bipolar plate (BP) geometry design on the performance of proton exchange membrane (PEM) fuel cells. Renewable and Sustainable Energy Reviews. 111(April): 236-60. doi: 10.1016/j.rser.2019.04.081.

[13] Heydari, M. H., Choupani, N., \& Shameli, M. (2011). Experimental and numerical investigation of mixed-mode interlaminar fracture of carbon-polyester laminated woven composite by using arcan setup. Applied Composite Materials, 18(6), 499-511. doi.org/10.1007/ s10443-011-9223-x.

[14] Hossein Abadi, R., Refah Torun, A., Mohammadali Zadeh Fard, A., Choupani, N., (2020). Fracture characteristics of mixed-mode toughness of dissimilar adherends (cohesive and interfacial fracture). Journal of Adhesion Science and Technology. 34(6): 599-615. doi: 10.1080/01694243.2019.1674102.

[15] Nikbakht, M., Choupani, N. (2008). Numerical investigation of delamination in carbon-epoxy composite using arcan specimen. International Journal of Mechanical, Industrial and Aerospace Engineering, 2(4), 259-266.

[16] Darııı, F., Aslan, Z., (2017). Characterization of Delamination Crack in Multidirectional E-glass/epoxy Composite under Mode I Loading. European Mechanical Science. 1(4): 117-28. doi: 10.26701/ ems.341788.

[17] Mubin, A.N.A., Bahrom, M.H., Azri, M., Ibrahim, Z., Rahim, N.A., Raihan, S.R.S., (2017). Analysis performance of proton exchange membrane fuel cell (PEMFC). IOP Conference Series: Materials Science and Engineering. 210(1). doi: 10.1088/1757-899X/210/1/012052.

[18] Qi, Z., Kaufman, A., (2002). PEM fuel cell stacks operated under dry-reactant conditions. Journal of Power Sources. 109(2): 469-76. doi: 10.1016/S0378-7753(02)00111-8.

[19] Yu, H.N., Kim, S.S., Suh, J. Do., Lee, D.G., (2010). Axiomatic design of the sandwich composite endplate for PEMFC in fuel cell vehicles. Composite Structures. 92(6): 1504-11. doi: 10.1016/j.compstruct.2009.10.026.

[20] Kim, J. S., Park, J. B., Kim, Y. M., Ahn, S. H., Sun, H. Y., Kim, K. H., Song, T. W. (2008). Fuel cell end plates: a review. International journal of Precision Engineering and Manufacturing, 9(1), 39-46.

[21] Asghari, S., Shahsamandi, M.H., Ashraf Khorasani, M.R., (2010). De- sign and manufacturing of end plates of a $5 \mathrm{~kW}$ PEM fuel cell. International Journal of Hydrogen Energy. 35(17): 9291-7. doi: 10.1016/j. ijhydene.2010.02.135.

[22] Shameli, M., \& Choupani, N. (2016). Fracture criterion of woven glass-epoxy composite using a new modified mixed-mode loading fixture. International Journal of Applied Mechanics, 8(02), 16-30. doi: $10.1142 / S 1758825116500150$

[23] Abaqus 6.11 Analysis User's Manual Volume II Analysis (2011), Dassault Systèmes, USA.

[24] Choupani, N., Heydari, M. H. (2014). A new comparative method to evaluate the fracture properties of laminated composite. International Journal of Engineering, 27(6), 991-1004.

[25] Choupani, N., (2008). Experimental and numerical investigation of the mixed-mode delamination in Arcan laminated specimens. Materials Science and Engineering A. 478(1-2): 229-42. doi: 10.1016/j. msea.2007.05.103.

[26] Ning, H., Li, J., Hu, N., Yan, C., Liu, Y., Wu, L., et al., (2015). Interlaminar mechanical properties of carbon fiber reinforced plastic laminates modified with graphene oxide interleaf. Carbon. 91: 224-33. doi: 10.1016/j.carbon.2015.04.054.

[27] Syarafuddin Salam, S., Mizamzul Mehat, N., Kamaruddin, S., (2019). Optimization of Laminated Composites Characteristics via integration of Chamis Equation, Taguchi method and Principal Component Analysis. IOP Conference Series: Materials Science and Engineering. 551(1). doi: 10.1088/1757-899X/551/1/012110.

[28] Choupani, N., (2008). Interfacial mixed-mode fracture characterization of adhesively bonded joints. International Journal of Adhesion and Adhesives. 28(6): 267-82. doi: 10.1016/j.ijadhadh.2007.08.002.

[29] Choupani, N., (2009). Characterization of fracture in adhesively bonded double-lap joints. International Journal of Adhesion and Adhesives. 29(8): 761-73. doi: 10.1016/j.ijadhadh.2009.05.002.

[30] Politis, D. J., Politis, N. J., Lin, J. (2021). Review of recent developments in manufacturing lightweight multi-metal gears. Production Engineering, 15(2), 235-262. doi: 10.1007/s11740-020-01011-5.

[31] Prini, F., Benson, S.D., Dow, R.S., (2017). The effect of laminate, stud geometry and advance coefficient on the deflection of a composite marine propeller. Progress in the Analysis and Design of Marine Structures - Proceedings of the 6th International Conference on Marine Structures, MARSTRUCT 2017. (April): 856-68. doi: 10.1201/9781315157368-111.

[32] Li, L.L., Wang, Z.Y., Bai, Z.C., Mao, Y., Gao, B., Xin, H.T., et al., (2006). Three-dimensional finite element analysis of weakened roots restored with different cements in combination with titanium alloy posts. Chinese Medical Journal. 119(4): 305-11. doi: 10.1097/00029330200602020-00007.

[33] Miura, M., Shindo, Y., Takeda, T., Narita, F., (2012). Interlaminar fracture characterization of woven glass/epoxy composites under mixed-mode II/III loading conditions at cryogenic temperatures. Engineering Fracture Mechanics. 96: 615-25. doi: 10.1016/j.engfracmech.2012.09.019.

[34] Hellier, A.K., Chaphalkar, P.P., Prusty, B.G., (2017). Fracture toughness measurement for aluminium 6061-T6 using notched round bars. 9th Australasian Congress on Applied Mechanics, ACAM 2017. 2017-Novem(November).

[35] Herráez, M., Fernández, A., Lopes, C.S., González, C., (2016). Strength and toughness of structural fibres for composite material reinforcement. Philosophical Transactions of the Royal Society A: Mathematical, Physical and Engineering Sciences. 374(2071). doi: 10.1098/ rsta.2015.0274. 
[36] Sockalingam, S., Gillespie, J.W., Keefe, M., (2015). Dynamic modeling of Kevlar KM2 single fiber subjected to transverse impact. International Journal of Solids and Structures. 67-68: 297-310. doi: 10.1016/j. ijsolstr.2015.04.031.

[37] Hosen, M.A., Alengaram, U.J., Jumaat, M.Z., Sulong, N.H.R., Darain, K.M. ud., (2017). Glass Fiber Reinforced Polymer (GFRP) Bars for Enhancing the Flexural Performance of RC Beams Using Side-NSM Technique. Polymers. 9(12): 180. doi: 10.3390/polym 9050180.

[38] Rao, A.R.M., Lakshmi, K., (2009). Multi-objective optimal design of hybrid laminate composite structures using scatter search. Journal of Composite Materials. 43(20): 2157-82. doi: $10.1177 / 0021998309339221$.

[39] Gdoutos, E.E. (2005) Fracture mechanics An Inroduction Second edition, Springer, Netherlands.

[40] Flom Y., Parker B. H., Chu H. P. (1989) Fracture Toughness of SiC/Al Metal Matrix Composite NASA Technical Memorandum 100745.

[41] Asby M. F., Jones D. R. H. (2006) Engineering Materials 2 An Introduction to Microstructures, Processing and Design Third Edition, Elsevier Linacre House, Burlington.

[42] Ozdil, F., Carlsson, L.A., Davies, P., (1998). Beam analysis of angle-ply laminate end-notched flexure specimens. Composites Science and Technology. 58(12): 1929-38. doi: 10.1016/S0266-3538(98)00018-9.

[43] Chalkley, P. and Rider, A., (2003). Toughening boron/epoxy bonded joints using the resin film infusion technique. Composites Part A: Applied Science and Manufacturing, 34(4), pp.341-348 doi: 10.1016/S1359-835X(03)00027-7.

[44] Zhu, Y., (2009). Characterization of Interlaminar Fracture Toughness of a Carbon/epoxy Composite Material, 249. A thesis Submitted in Partial Fulfillment of the Requirements for the Degree of Master of Science, The Pennsylvania State University. 